\title{
PENGARUH APLIKASI MIKORIZA DARI SUMBER YANG BERBEDA TERHADAP PERTUMBUHAN BIBIT KAKAO DI TANAH ULTISOL
}

\section{THE INFLUENCE OF MYCORRHIZA FROM DIFFERENT SOURCES ON THE GROWTH OF CACAO SEEDS IN ULTISOL SOIL}

\section{Edi Susilo1)}

\author{
1)Program Studi Agroteknologi, Fakultas Pertanian Universitas Ratu Samban \\ Jl. Jenderal Sudirman No. 87 Arga Makmur Kabupaten Bengkulu Utara \\ Korespondensi : e-mail : susilo_agr@yahoo.com
}

\begin{abstract}
ABSTRAK
Mikoriza yang berasal dari sumber yang berbeda dimungkinkan mempunyai potensi yang berbeda terhadap pertumbuhan bibit kakao khususnya di tanah Ultisol. Tujuan penelitian ini adalah untuk mendapatkan sumber mikoriza terbaik pada pertumbuhan bibit kakao di tanah Ultisol. Penelitian dilaksanakan di rumah plastik Fakultas Pertanian Universitas Ratu Samban Arga Makmur Kabupaten Bengkulu Utara pada bulan Nopember 2016 sampai Maret 2017. Bahan penelitian yang digunakan adalah benih kakao Hibrida F1, isolat mikoriza, dan tanah Ultisol. Penelitian dilaksanakan menggunakan Rancangan Acak Lengkap faktor tunggal. Perlakuan sumber mikoriza terdiri atas lima taraf yaitu tanpa isolat mikoriza, isolat mikoriza berasal dari Kepahyang, Rejang Lebong, Bengkulu Utara, dan Kaur. Hasil penelitian menunjukkan bahwa sumber isolat mikoriza berpengaruh nyata terhadap variabel tinggi tanaman, panjang daun dan luas daun. Sumber isolat mikoriza dari Kepahyang menghasilkan tinggi tanaman tertinggi sebesar 19,82 cm namun tidak berbeda nyata dengan Kaur, Rejang Lebong maupun Bengkulu Utara kecuali kontrol. Sumber isolat mikoriza yang berasal dari Kaur menghasilkan panjang daun dan luas daun tertinggi masing-masing 12,47 cm dan $38,31 \mathrm{~cm}^{2}$, namun tidak berbeda nyata dengan semua sumber mikoriza lainnya, kecuali kontrol.
\end{abstract}

Kata kunci : mikoriza, kakao, bibit, sumber, Ultisol.

\begin{abstract}
Mycorrhizae originating from different sources are possible to have different potential for the growth of cacao seedlings. This study aims to obtain the best sources of mycorrhiza in the growth of cacao seedlings in Ultisol soil. The study was carried out in plastic houses belonging to the Faculty of Agriculture, University of Ratu Samban Arga Makmur, Bengkulu Utara in November 2016 to March 2017. The study was carried out using a single factor Completely Randomized Design. Mycorrhizal treatment consisted of five levels, namely control, mycorrhizal sources from Kepahyang, Rejang Lebong, Bengkulu Utara, and Kaur. The results showed that the source of mycorrhizal isolates had a significant effect on variable plant height, leaf length and leaf area. Sources of mycorrhizal isolates from Kepahyang which produced the highest plant height of $19.82 \mathrm{~cm}$ and Kaur produced the highest leaf length and leaf area of $12.47 \mathrm{~cm}$ and $38.31 \mathrm{~cm}^{2}$ respectively, but were not significantly different from all other mycorrhizal sources, except controls.
\end{abstract}

Keywords: mycorrhiza, cocoa, seeds, sources, Ultisol. 


\section{PENDAHULUAN}

Kakao merupakan salah satu komoditas perkebunan yang berperan sebagai penghasil devisa negara, penciptaan lapangan kerja, sumber pendapatan masyarakat, mendorong agroindustri kakao, dan pelestarian lingkungan. Produksi kakao Indonesia tahun 2015, luas 1.709.284 ha dengan produksi 593.331 ton, volume ekspor 333.679 ton dan volume impor 293.780 ton. Produksi kakao untuk Propinsi Bengkulu, luas 13.125 ha dengan produksi 4.039 ton (Direktorat Jenderal Perkebunan, 2016).

Tanah Ultisol merupakan bagian terluas dari lahan kering yang tersebar luas di pulau Sumatera, Kalimantan, Sulawesi, Papua serta sebagian kecil di pulau Jawa, terutama di wilayah Jawa Barat. Luas tanah Ultisol di Indonesia dari tahun-ketahun semakin meluas, sejalan dengan makin meningkatnya intensitas penebangan hutan, baik dalam skala besar maupun dalam skala kecil yang dilakukan oleh masyarakat setempat untuk memenuhi kebutuhan kayu bakar, bahan bangunan dan keperluan berladang (Munir, 1996). Kelemahan tanah Ultisol sebagai media tumbuh tanaman khususnya pembibitan tanaman adalah karena tanah tersebut umumnya bereaksi masam. Oleh karena itu untuk meningkatkan pertumbuhan bibit tanaman diperlukan media tumbuh yang baik bagi tanaman (Rajagukguk dkk, 2013).

Tanah Ultisol mempunyai $\mathrm{pH}$ tanah dan kejenuhan basa (berdasarkan jumlah kation) yang rendah $<35$. Kejenuhan $\mathrm{Al}$ dan $\mathrm{Fe}$ cukup tinggi merupakan racun bagi tanaman dan mengakibatkan adanya fiksasi $\mathrm{P}$ sehingga unsur P kurang tersedia. Kapasitas Tukar Kation (KTK) yang relatif rendah memperlihatkan kandungan bahan organik yang rendah pada semua horizon kecuali di horizon A (bagian atas) yang sangat tipis. Tanah Ultisol mempunyai daya simpan air dan kemantapan agregat tanah menyebabkan tanah ini rentan terhadap erosi dan menjadi kendala pada areal berlereng. Walaupun tanah ultisol diidentikkan dengan tanah yang tidak subur, dimana mengandung bahan organik yang rendah, nutrisi rendah dan $\mathrm{pH}$ rendah (kurang dari 5,5) tetapi bisa dimanfaatkan untuk lahan pertanian potensial jika dilakukan pengelolaan yang memperhatikan kendala yang ada (Silaen dkk, 2013).

Upaya yang dapat dilakukan untuk mengatasi keterbatasan pupuk dan semakin tingginya harga pupuk serta kerusakan lingkungan akibat penggunaan pupuk kimia yang berlebihan adalah dengan pemanfaatan bioteknologi tanah seperti mikroba tanah dan teknologi pupuk alam (Nasaruddin, 2012). Mikoriza 
adalah suatu bentuk hubungan simbiosis mutualistik antara jamur tanah kelompok tertentu dan perakaran tumbuhan tingkat tinggi. Cendawan mikoriza arbuskular memiliki hifa yang berfungsi memperpanjang akar untuk membantu menyerap dan mentransfer hara tanah dan air ke tanaman. Cendawan mikoriza arbuskular adalah mikroba tanah yang hidup bersimbiosis secara mutualisme dengan tanaman. Dari hubungan ini terjadi kerjasama yang saling menguntungkan (Prihandana dan Hendroko, 2006). Mikoriza mampu memberikan ketahanan terhadap kekeringan dengan meningkatnya kemampuan tanaman untuk menghindari pengaruh langsung dari kekeringan dengan jalan meningkatkan penyerapan air melalui sistem gabungan akar dan mikoriza (Sasli, 2004). Inokulasi mikoriza arbuskular berkorelasi positif secara linier terhadap pertumbuhan bibit kakao sampai $10 \mathrm{~g}$ per tanaman dan berkorelasi positif secara kuadratik terhadap berat kering akar bibit kakao pada umur 4 bulan setelah tanam (Nasaruddin, 2011).

Penggunaan cendawan mikoriza sebagai pupuk biologis merupakan salah satu alternatif mengurangi penggunaan pupuk anorganik dan pestisida. Tanaman yang membutuhkan $\mathrm{P}$ yang tinggi dengan kemampuan menyerap hara rendah akan berkorelasi positif dengan tingkat ketergantungan pada mikoriza. Selain phosfat, mikoriza juga mampu meningkatkan penyerapan unsur hara $\mathrm{N}$ karena adanya enzim nitrate-reductase, sehingga sifatnya mempunyai kemampuan untuk menyerap nitrat. Unsur hara lainnya yang dapat diserap oleh mikoriza, antara lain $\mathrm{K}, \mathrm{Mg}, \mathrm{Cu}, \mathrm{Zn}, \mathrm{S}$, Mo dan B. Adanya simbiosis antara mikoriza dan tanaman dapat membantu meningkatkan ketersediaan unsur hara bagi tanaman karena kemampuan dari hifa eksternal dalam mengeksploitasi tanah media tumbuh di daerah rhizosper. Kemampuan dari hifa eksternal tersebut dalam mengeksploitasi tanah media tumbuh akan mampu meningkatkan kemampuan dari tanaman dalam beradaptasi berbagai cekaman, antara lain terhadap cekaman kekeringan, defisiensi hara, cekaman aluminium, fero dan lain-lain (Harja, 2015). Penelitian ini bertujuan untuk mendapatkan sumber mikoriza terbaik pada pertumbuhan bibit kakao di tanah Ultisol.

\section{BAHAN DAN METODE}

Penelitian dilaksanakan di Rumah Plastik Fakultas Pertanian Universitas Ratu Samban Arga Makmur Kabupaten Bengkulu Utara pada bulan Nopember 2016 sampai Maret 2017. Bahan penelitian yang digunakan adalah tanah Ultisol, benih kakao, zeolit, dan sampel 
tanah dari 4 lokasi kabupaten yang ada di Propinsi Bengkulu. Alat yang digunakan adalah saringan, cawan petri, gunting, autoclave, gelas beaker, kaca preparat, objek glass, mikroskop, timbangan, kamera, pinset, polybag, cangkul, penggaris, dan alat tulis.

\section{Penelitian} dilaksanakan menggunakan Rancangan Acak Lengkap dengan pola faktor tunggal. Perlakuan mikoriza terdiri atas lima taraf yaitu tanpa isolat mikoriza, mikoriza dari Kepahyang, Rejang Lebong, Bengkulu Utara dan Kaur. Penelitian diawali dengan pengambilan sampel tanah di sekitar perakaran tanaman kakao. Pengambilan sampel tanah dan akar dilakukan di perakaran tanaman kakao dari 4 kabupaten di Propinsi Bengkulu. Metode pengambilan sampel tanah dan akar dilakukan secara diagonal di sekitar perakaran kakao. Masing-masing sampel diambil sebanyak $1.000 \mathrm{~g}$ di sekitar perakaran tanaman kakao, jarak pengambilan $25 \mathrm{~cm}$ dari pangkal batang dengan kedalaman $25 \mathrm{~cm}$. Sampel yang diperoleh dimasukkan dalam kantong plastik dan diberi label sebagai kode sumber isolat mikoriza.

Isolasi dan identifikasi mikoriza dilakukan dengan cara menimbang sampel tanah sebanyak 100 g, kemudian dimasukkan dalam gelas beaker $1.000 \mathrm{ml}$ dan ditambah air sampai volume 1 liter.
Tanah tersebut diaduk selama \pm 10 menit sampai teraduk rata dan agegat tanah pecah dengan tangan supaya spora terbebas dari tanah dan diamkan selama \pm 5 menit. Kemudian dituang ke dalam saringan bertingkat dengan diameter lubang $1 \mathrm{~mm}, 500 \mu \mathrm{m}, 212 \mu \mathrm{m}, 106 \mu \mathrm{m}$, $53 \mu \mathrm{m}$ (prosedur ini diulang sebanyak 2-3 kali) dan dibilas dengan air kran dituang ke dalam cawan petri untuk dilakukan pengamatan spora di bawah mikroskop.

Spora mikoriza diperbanyak pada media tanam menggunakan tanah steril dengan campuran zeolit perbandingan 1:1, dimasukkan ke dalam gelas plastik. Spora mikoriza yang diperoleh diinokulasi ke bibit sorgum dan ditanam pada media tanah yang telah dicampurkan zeolit. Pemeliharaan tanaman dilakukan selama 1 bulan. Benih yang digunakan pada penelitian ini adalah kakao Hibrida F1 berasal dari Pusat Penelitian Kopi dan Kakao Jember. Media yang digunakan untuk tanam kakao adalah tanah ultisol.

Penanaman dan aplikasi mikoriza dilakukan dengan cara menanam benih kakao pada media tanah dalam polybag sebanyak 1 biji per polybag. Caranya yaitu dengan membuat lubang pada media tanah dalam polybag sedalam $3 \mathrm{~cm}$, kemudian benih kakao dimasukkan ke dalam lubang tanam setelah mikoriza dimasukkan terlebih dahulu, selanjutnya ditutup kembali dengan tanah dan 
dilakukan penyiraman secukupnya. Aplikasi mikoriza sebanyak $20 \mathrm{~g}$ per lubang tanam.

Pemeliharaan tanaman meliputi penyiraman sehari satu kali, pengendalian hama dan penyakit menggunakan pestisida berbahan aktif Propenofos atau disesuaikan dengan jenis serangan hama atau penyakit. Penyiangan gulma dilakukan secara manual dengan mencabut gulma yang tumbuh di polybag. Variabel pengamatan meliputi tinggi tanaman, jumlah daun, panjang daun, lebar daun, dan luas daun. Data pengamatan dianalisis dengan sidik ragam untuk mengetahui pengaruh perlakuan yang dicobakan dan apabila dari hasil analisis tersebut berpengaruh nyata maka diuji lanjut Duncan pada taraf kepercayaan 95\% (Mattjik dan Sumertajaya, 2006).

\section{HASIL DAN PEMBAHASAN}

Pengamatan terhadap variabel pertumbuhan bibit kakao meliputi tinggi tanaman, jumlah daun, panjang daun, lebar daun dan luas daun disajikan Tabel 1. Berdasarkan hasil uji $\mathrm{F}$ menunjukkan bahwa perlakuan sumber isolat mikoriza berpengaruh nyata terhadap variabel tinggi tanaman, panjang daun dan luas daun, namun tidak berpengaruh nyata terhadap variabel jumlah daun dan lebar daun. Terdapat perbedaan antara perlakuan penggunaan mikoriza dan tanpa penggunaan mikoriza. Pada perlakuan mikoriza menunjukkan pertumbuhan yang lebih baik. Hal ini ditandai dengan pertumbuhan yang lebih cepat dan lebih subur jika dibandingkan dengan tanpa menggunakan mikoriza. Hal ini sesuai dengan pendapat Lucia dkk, (1998) bahwa tanaman yang diberi inokulasi cendawan mikoriza (endomikoriza, ektomikoriza dan gabungan keduanya) menghasilkan pertumbuhan yang lebih baik dibandingkan tanaman yang tidak diberi inokulasi cendawan mikoriza. Inokulasi cendawan mikoriza nyata meningkatkan tinggi tanaman, luas daun, bobot basah tajuk dan bobot kering tajuk.

Pada variabel tinggi tanaman, perlakuan sumber isolat mikoriza menunjukkan berpengaruh nyata. Sumber isolat mikoriza yang berasal dari Kepahyang menghasilkan tinggi tanaman tertinggi sebesar 19,81 cm namun tidak berbeda nyata dengan sumber isolat mikoriza yang berasal dari Kabupaten Rejang Lebong, Bengkulu Utara, dan Kaur. Semua sumber isolat mikoriza berbeda nyata jika dibandingkan dengan kontrol (tanpa perlakuan mikoriza). Pada variabel tinggi tanaman, perlakuan sumber isolat mikoriza menunjukkan berpengaruh nyata. Hal ini menunjukkan bahwa semua perlakuan isolat mikoriza selalu memberikan respon yang baik terhadap 
tanaman, khususnya tinggi tanaman. Namun diantara sumber isolat yang berjumlah 4 sumber, yang menghasilkan respon terhadap tinggi tanaman yang terbaik adalah isolat yang berasal dari Kepahyang. Adanya respon aplikasi mikoriza terhadap tinggi tanaman kakao ini menunjukkan bahwa mikoriza bersimbiosis dengan akar tanaman kakao yang dapat meningkatkan penyerapan unsur hara di dalam tanah, sehingga tanaman mampu meningkatkan laju pertumbuhannya. Menurut Kartika dkk (2013), bahwa tanaman bibit karet yang bermikoriza memiliki pertumbuhan yang lebih baik daripada yang tidak bermikoriza. Hal ini diakibatkan karena mikoriza secara efektif dapat meningkatkan penyerapan unsur hara di dalam tanah sehingga menghasilkan pertumbuhan tanaman lebih baik. Sistem perakaran pada tanaman yang bersimbiosis dengan mikoriza akan lebih baik karena adanya hifa mikoriza yang sangat halus dan panjang di bulu-bulu akar, sehingga memungkinkan akar tanaman menyerap air dan unsur hara lebih banyak. Menurut Hastuti dkk (2007) juga berpendapat bahwa inokulasi jamur mikoriza arbuskula mampu meningkatkan tinggi, berat segar tajuk, panjang dan jumlah akar, serta nisbah berat kering tajuk dan berat kering akar bibit kakao daripada bibit kakao yang tidak diinokulasi dengan jamur bersangkutan.

Pada variabel jumlah daun bibit kakao, perlakuan sumber isolat mikoriza menunjukkan tidak berpengaruh nyata. Terdapat kecenderungan bahwa sumber isolat mikoriza yang berasal dari Bengkulu Utara menghasilkan jumlah daun yang lebih banyak (4,80 helai) jika dibandingkan perlakuan sumber isolat mikoriza dari berbagai daerah lainnya ditunjukkan Tabel 2. Hal ini diduga bahwa mikoriza telah bekerja dan mampu meningkatkan penyerapan air dan unsur hara yang berada di dalam tanah.

Tabel 1. Hasil uji F aplikasi mikoriza dari sumber yang berbeda terhadap pertumbuhan bibit kakao di tanah Ultisol

\begin{tabular}{clcc}
\hline No & \multicolumn{1}{c}{ Variabel } & Sumber mikoriza & Koefisiensi keragaman \\
\hline 1 & Tinggi tanaman & $3,04 *$ & 9,28 \\
2 & Jumlah daun & $1,38 \mathrm{tn}$ & 12,75 \\
3 & Panjang daun & $3,03 *$ & 17,09 \\
4 & Lebar daun & $2,69 \mathrm{tn}$ & 16,97 \\
5 & Luas daun & $3,19 *$ & 28,41 \\
\hline
\end{tabular}

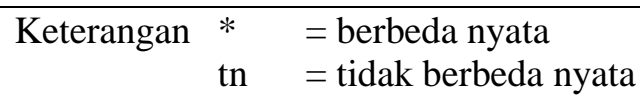


Tabel 2. Rataan tinggi tanaman dan jumlah daun bibit kakao dengan aplikasi mikoriza dari sumber yang berbeda terhadap pertumbuhan bibit kakao di tanah Ultisol

\begin{tabular}{lcc}
\hline \multicolumn{1}{c}{ Sumber mikoriza } & Tinggi tanaman $(\mathrm{cm})$ & Jumlah daun (helai) \\
\hline Kontrol & $16,61 \mathrm{~b}$ & $4,41 \mathrm{a}$ \\
Kepahyang & $19,82 \mathrm{a}$ & $4,01 \mathrm{a}$ \\
Rejang Lebong & $19,71 \mathrm{a}$ & $4,60 \mathrm{a}$ \\
Bengkulu Utara & $19,50 \mathrm{a}$ & $4,80 \mathrm{a}$ \\
Kaur & $19,71 \mathrm{a}$ & $4,41 \mathrm{a}$ \\
\hline
\end{tabular}

Keterangan : Angka-angka yang diikuti huruf yang sama pada kolom yang sama tidak berbeda nyata pada uji DMRT taraf 5\%.

Menurut Putri dkk, (2016), pemberian mikoriza mampu meningkatkan penyerapan air dan hara sehingga mampu meningkatkan hasil asimilat yang nantinya digunakan dalam pembentukan daun pada bibit cengkeh. Ditambahkan juga bahwa rata-rata jumlah daun tanaman cengkeh yang diberi mikoriza pada perlakuan diinokulasi mikoriza secara statistik memberi pengaruh nyata terhadap jumlah daun dibandingkan perlakuan yang tidak diinokulasi mikoriza. Selanjutnya Prasetiyo (2011) juga berpendapat tanaman jati memberikan respon yang positif terhadap pemberian mikoriza yang dibuktikan semua parameter pertumbuhan yang meliputi tinggi, diameter dan jumlah daun tanaman dengan inokulasi mikoriza memiliki pertumbuhan yang lebih baik dibandingkan kontrol yaitu sebesar 164,87 $\%, 174,77 \%$, dan $121,96 \%$.
Pada variabel panjang daun bibit kakao, perlakuan sumber isolat mikoriza menunjukkan berpengaruh nyata. Sumber isolat mikoriza yang berasal dari Kaur, Kepahyang, maupun Rejang Lebong menghasilkan panjang daun yang lebih panjang masing-masing $12,47 \mathrm{~cm}, 11,63$ $\mathrm{cm}$ dan $11,27 \mathrm{~cm}$, namun tidak berbeda nyata dengan sumber mikoriza Bengkulu Utara dan berbeda nyata dengan kontrol $(8,65 \mathrm{~cm})$ ditunjukkan Tabel 3. Hal ini menunjukkan bahwa telah terjadi simbiosis antara akar tanaman dengan mikoriza dalam proses penyerapan unsur hara dan air, sehingga bisa memperbaiki dan meningkatkan pertumbuhan tanaman khususnya perpanjangan daun. Hal ini sesuai pendapat Idhan dan Nursjamsi (2016) yang menyatakan bahwa perlakuan mikoriza menunjukkan pertumbuhan daun kakao tertinggi, sedangkan pertumbuhan daun kakao terendah terdapat pada perlakuan tanpa mikoriza. Jamur mikoriza 
yang bersimbiosis dengan akar tanaman kakao mampu meningkatkan serapan unsur hara $\mathrm{N}, \mathrm{P}$, dan $\mathrm{K}$ serta meningkatkan efisiensi penggunaan air tanah pada pertumbuhan dan perkembangan tanaman.

Pada variabel lebar daun bibit kakao, perlakuan sumber isolat mikoriza menunjukkan tidak berpengaruh nyata. Terdapat kecenderungan bahwa sumber isolat mikoriza yang berasal dari Kaur menghasilkan lebar daun yang lebih lebar 4,85 cm jika dibandingkan kontrol sebesar $3,47 \mathrm{~cm}$. Pada umumnya semua perlakuan mikoriza cenderung menghasilkan lebar daun kakao yang lebih lebar jika dibandingkan dengan tanpa perlakuan mikoriza ditunjukkan Tabel 3. Hal ini sependapat dengan hasil penelitian Kartika dkk, (2013) yang menyatakan bahwa perlakuan mikoriza tidak berbeda nyata pada lebar daun, namun terdapat kecenderungan bahwa perlakuan mikoriza menunjukkan pertumbuhan lebar daun bibit karet terbaik jika dibandingkan perlakuan tanpa mikoriza. Meskipun menunjukkan tidak terdapat perbedaan yang nyata namun aplikasi mikoriza selalu menghasilkan pertumbuhan tanaman yang lebih baik. Sesuai pendapat Lucia dkk, (1998) yang menyatakan bahwa inokulasi cendawan mikoriza pada tanaman kakao umumnya menghasilkan pertumbuhan daun yang lebih baik daripada tanaman yang tidak diberi perlakuan mikoriza. Selanjutnya menurut penelitian Basuki (2013) bahwa lebar daun tanaman tebu umur empat minggu setelah aplikasi VAM mampu meningkatkan lebar daun sebesar 22,2 \% dibandingkan dengan tanpa VAM.

Tabel 3. Rataan panjang daun, lebar daun, dan luas daun bibit kakao dengan aplikasi mikoriza dari sumber yang berbeda terhadap pertumbuhan bibit kakao di tanah Ultisol

\begin{tabular}{lccc}
\hline \multicolumn{1}{c}{ Sumber mikoriza } & $\begin{array}{c}\text { Panjang daun } \\
(\mathrm{cm})\end{array}$ & $\begin{array}{c}\text { Lebar daun } \\
\text { (helai) }\end{array}$ & $\begin{array}{c}\text { Luas daun } \\
\left(\mathrm{cm}^{2}\right)\end{array}$ \\
\hline Kontrol & $8,65 \mathrm{~b}$ & $3,47 \mathrm{a}$ & $20,43 \mathrm{~b}$ \\
Kepahyang & $11,63 \mathrm{a}$ & $4,47 \mathrm{a}$ & $32,95 \mathrm{a}$ \\
Rejang Lebong & $11,27 \mathrm{a}$ & $4,51 \mathrm{a}$ & $31,79 \mathrm{ab}$ \\
Bengkulu Utara & $10,47 \mathrm{ab}$ & $4,05 \mathrm{a}$ & $26,45 \mathrm{ab}$ \\
Kaur & $12,47 \mathrm{a}$ & $4,85 \mathrm{a}$ & $38,31 \mathrm{a}$
\end{tabular}

Keterangan : Angka-angka yang diikuti huruf yang sama pada kolom yang sama tidak berbeda nyata pada uji DMRT taraf $5 \%$. 
Pada variabel luas daun, perlakuan sumber isolat mikoriza menunjukkan berpengaruh nyata. Sumber isolat mikoriza Kaur menghasilkan luas daun terluas $38,31 \mathrm{~cm}^{2}$ dan berbeda nyata dengan kontrol 20,43 $\mathrm{cm}^{2}$. Sumber isolat mikoriza Kaur menghasilkan luas daun terluas namun tidak berbeda nyata dengan Kepahyang, Rejang Lebong, dan Bengkulu Utara. Perlakuan kontrol menghasilkan luas daun terendah ditunjukkan Tabel 3. Hal ini menunjukkan bahwa pertumbuhan tanaman kakao yang diberi aplikasi mikoriza mampu meningkatkan pertumbuhan vegetatif tanaman kakao terutama luas daun. Menurut Purba et al., (2014) pertumbuhan vegetatif tanaman berpengaruh terhadap pemberian mikoriza. Pemberian mikoriza dapat menyediakan unsur hara esensial (hara penting) yang dapat menyusun pertumbuhan vegetatif tanaman seperti unsur $\mathrm{P}$ untuk pembentukan energi dan meningkatkan kecepatan pertumbuhan tanaman. Tersedianya unsur hara ini karena dibantu dengan adanya mikoriza yang bersimbiosis dengan akar tanaman. Perakaran tanaman yang terinfeksi oleh mikoriza akan memiliki daya jelajah yang luas dikarenakan hifa-hifa dari mikoriza akan keluar dari bagian korteks menembus lapisan kulit luar akar tanaman.

\section{KESIMPULAN}

Sumber isolat mikoriza berpengaruh nyata terhadap variabel tinggi tanaman, panjang daun dan luas daun. Sumber isolat mikoriza dari Kepahyang menghasilkan tinggi tanaman tertinggi sebesar 19,82 cm namun tidak berbeda nyata dengan Kaur, Rejang Lebong maupun Bengkulu Utara kecuali kontrol. Sumber isolat mikoriza yang berasal dari Kaur menghasilkan panjang daun dan luas daun tertinggi masingmasing $12,47 \mathrm{~cm}$ dan $38,31 \mathrm{~cm}^{2}$, namun tidak berbeda nyata dengan semua sumber mikoriza lainnya, kecuali kontrol.

\section{DAFTAR PUSTAKA}

Basuki. 2013. Pengaruh Cendawan Mikoriza Arbuskula (CMA) terhadap karakteristik agonomi tanaman tebu sistem tanam bagal satu. Menara Perkebunan, Vol. 5.

Direktorat Jenderal Perkebunan, Kementrian Pertanian. 2016. Statistik Perkebunan Indonesia, 2015-2017 Kakao. Sekretariat Direktorat Jenderal Perkebunan Kementrian Pertanian. http://ditjenbun.pertanian.go.id.

Harja Z. U. 2015. Budidaya Padi pada Lahan Marjinal. Penerbit Andi, Yogyakarta.

Hastuti B. P, Astuti M, Kurniadhi A. 2007. Pengaruh pemberian kompos limbah kubis dan inokulasi jamur mikoriza arbuskula terhadap pertumbuhan bibit kakao. Buletin Ilmiah, Vol. 103.

Idhan, A., Nursjamsi. 2016. Aplikasi mikoriza dan pupuk organik terhadap pertumbuhan tanaman 
kakao (Theobroma cacao L.) di Kabupaten Gowa. Jurnal Perspektif. Vol 1 (1) : 1-11.

Kartika, E., Salim, H., Fahrizal. 2013. Tanggap bibit karet (Hevea brasiliensis Mull. Arg) terhadap pemberian mikoriza vesikular arbuskular dan pupuk fosfor di polybag. Program Studi Agroteknologi Fakultas Pertanian Universitas Jambi. Vol 2 (2) : 5869.

Lucia, Y., Yahya, S., Fakuara, Y, M. 1998. Efisiensi pemberian air pada bibit kakao yang diinokulasi cendawan mikoriza. Bul. Argon. Vol 26 (1) : 1-8.

Mattjik A A, Sumertajaya I M. 2006. Perancang Percobaan dengan Aplikasi SAS dan MINITAB. Bogor: IPB Press.

Munir, M.1996. Tanah - Tanah Utama Indonesia. PT Dunia Pustaka Jaya. Jakarta.

Nasaruddin. 2011. Respon pertumbuhan bibit kakao terhadap inokulasi Azotobacter dan Mikoriza. Makassar, J. Agivigor Vol. 16.

Nasaruddin. 2012. Respon pertumbuhan bibit kakao terhadap inokulasi Azotobacter dan mikoriza. $J$. Agrivigor. Vol 11 (2) : 300-315.

Prasetiyo N. A. 2011. Aplikasi pemanfaatan cendawan mikoriza arbuskula (CMA) terhadap pertumbuhan Jati (Tectona gandis). Tekno Hutan Tanaman Vol. 5 No. (97): 93 - 97.
Prihandana R dan Hendroko R. 2006. Petunjuk Budidaya Jarak Pagar. Jakarta.

Purba, O, R, P., Rahmawati, N., Kardhinata, H, E., Sahar, S. 2014. Efektivitas beberapa jenis fungi mikoriza arbuskular terhadap pertumbuhan tanaman karet (Hevea brassiliensis Muell. Arg.) di pembibitan. Jurnal Online Agroteknologi. Vol 2 (2) : 919 932.

Putri, T, O, A., Hadisutrisno, B., Wibowo, A. 2016. Pengaruh inokulasi mikoriza arbuskular terhadap pertumbuhan bibit dan intensitas penyakit bercak daun Cengkeh. Jurnal Pemuliaan Tanaman Hutan. Vol 10 (2) : 145-154.

Rajagukguk, P., Siagian, B., Lahay, R, R. 2013. Respon pertumbuhan bibit kakao (Theobroma cacao L.) terhadap pemberian pupuk guano dan KCl. Jurnal Online Agroekoteknologi. Vol 3 (1) : 2032.

Sasli, I. 2004. Peranan Mikoriza Vesikula Arbuskular (MVA) dalam Peningkatan Resistensi Tanaman terhadap Cekaman Kekeringan. Makalah Pengantar ke Falsafah Sains (PPS702). Sekolah Pasca Sarjana S3. Institut Pertanian Bogor. Vol. 12.

Silaen, S, O., Sitepu, E, F., Siagian, B. 2013. Respons pertumbuhan bibit kakao terhadap vermikompos dan pupuk P. Jurnal Online Agroteknologi. Vol 1 (4). 